tion. The techniques developed can assist orchard managers to impose selection intensity that achieves an appropriate balance of genetic gain and diversity in orchard crops. Finally, seed demand and the impact of tree removal on immediate and long-term seed yield should be also considered.

\section{Acknowledgements}

This work was funded by the Korea Forest Research Institute. The authors gratefully thank Mr. JANG, K.W. for collection of fertility data and for performance of genetic thinning operations in the orchard.

\section{References}

ADAms, W. T. and J. Burczyk (1998): Magnitude and implications of gene flow in gene conservation reserves. p.1-16 in Forest conservation genetics: Principles and practice. BoYle, T., et al. (eds.). CIFOR Australia.

Bondesson, L. and D. LindGREN (1993): Optimal utilization of clones and genetic thinning of seed orchards. Silvae Genet. 42: 157-163.

CotTERILl, P. P. and N. JACKSON (1989): Gains expected from clonal orchards under alternative breeding strategies. For. Sci. 35(1): 183-196.

El-KASSABY, Y. A. and H. J. BARCLAY (1992): Cost of reproduction in Douglas-fir. Can. J. Bot. 70: 1429-1432.

EL-Kassaby, Y. A., A. M. K. FAshler and M. CRown (1989): Variation in fruitfulness in a Douglas-fir seed orchard and its effect on crop management decisions. Silvae Genet. 38: 113-121.

GRIFFIN, A. R. (1982): Clonal variation in radiata pine seed orchards. I. Some flowering, cone and seed production traits. Aust. For. Res. 12: 295-302.

GREGORIUS, H. (1989): Characterization and analysis of mating system. Ekopan Verlag, Germany. 158 p.

GÖMÖRY, D., R. BRUCHANIK and R. LONGAUER (2003): Fertility variation and flowering asynchrony in Pinus sylvestrys: consequences for the genetic structure of progeny in seed orchards. For. Ecol. Manage 174: 117-126.
GÖMÖRY, D., R. BRUCHANIK and L. PAUlE (2000): Effective population number estimation of three Scots pine (Pinus sylvestris L.) seed orchards based on an integrated assessment of flowering, floral phenology, and seed orchard design. For. Genet. 7: 65-75.

KANG, K. S. (2001): Genetic gain and gene diversity of seed orchard crops. Acta Universitatis Agriculturae Sueciae, Silvestria 187. 75 p.

Kang, K.S. and D. Lindgren, 1999: Fertility variation among clones of Korean pine (Pinus koraiensis S. et Z.) and its implications on seed orchard management. For. Genet. 6: 191-200.

Kang, K. S., A. D. Bila, A. M. HarJu and D. Lindgren (2003a): Fertility variation in forest tree populations. Forestry 76: 329-344.

Kang, K. S., Y. A. El-Kassaby, W. Y. Choi, S. U. Han and C. S. KIM (2003b): Changes in genetic gain and diversity caused by genetic thinning in a clonal seed orchard of Pinus densiflora. Silvae Genet. 52: 220-223.

KJÆR, E. D. (1999): Sustainable use of forest genetic resources. Ph. D. Thesis. Royal Veterinary and Agriculture University, Horsholm, Denmark, $67 \mathrm{p}$.

LINDGREN, D. and Y. A. El-KASSABY (1989): Genetic consequences of combining selective cone harvesting and genetic thinning in clonal seed orchards. Silvae Genet. 38: $65-70$.

LindGREN, D. and T. J. Mullin (1998): Relatedness and status number in seed orchard crops. Can. J. For. Res. 28: $276-283$.

Lindgren, D., L. GEA and P. JefFerson (1996): Loss of genetic diversity monitored by status number. Silvae Genet. 45: 52-59.

Mirov, N. T. (1967): The genus Pinus. The Roland Press Company, New York. p. 261-297.

NCSU (2001): NC State University-Industry Cooperative Tree Improvement Program. 45 ${ }^{\text {th }}$ annual report. Department of Forestry, College of Forest Resources, NC State University, Raleigh, NC. 34 p.

Rosvall, O. (1999): Enhancing gain from long-term forest tree breeding while conserving genetic diversity. Acta Universitatis Agriculturae Sueciae, Silvestria 109, Umeå, Sweden, 65 p.

\title{
Genetic Variation and Realized Genetic Gain From Black Pine Tree Improvement
}

\author{
By D. MATZIRIS ${ }^{*}$
}

(Received $15^{\text {th }}$ November 2004)

\section{Summary}

In 1978 a 10 ha clonal seed orchard of black pine (Pinus nigra Arnold) was established in the area of Koumani in the western part of Peleponnesos, Greece. The orchard comprises 52 clones derived from intensive-

\footnotetext{
*) Forest research Institute, Athens Greece.

Present Address: Antifilou 46, 15771, Athens Greece
}

ly selected plus trees in the natural forest of black pine of Peloponnesos. In 1991 three open pollinated progeny tests were established in Peloponnesos, proximal to the villages of Raches, Vlachokerasia and Vamvakou. Seedlings from 52 families including a commercial check (CC) were planted in each one of the three locations. Assessments were made when the trees were 4,7 and 9 years respectively, with the following results. 
The variation among families for growth characteristics were highly significant in all locations examined. In the combined analyses of variance over the three locations, significant differences among families were also detected, while the family $x$ location interaction effect was not significant. This indicates that the seed produced from the seed orchard can be freely used over the environments of the three experimental plantings, which are representative of the broad area of Peloponnesos.

Narrow sense heritability estimates on individual tree basis $\left(h^{2}\right)$ were variable depending on the characteristic, age of assessment and the location of the experimental plantings. The estimates of $\mathrm{h}^{2}$ in Vlachokerasia for height (HT) were $0.21,0.40$ and 0.43 at the ages of 4,7 and 9 years respectively. In Raches the corresponding $\mathrm{h}^{2}$ values for HT were nearly the same in all ages $(0.29$, 0.28 and 0.31 at 4,7 and 9 years respectively) and stable but little higher $(0.31,0.28$ and 0.31$)$ at the Vamvakou experimental planting. The heritability values for HT estimated over the three location, were relatively low $(0.25,0.23$ and 0.19$)$ at the ages 4,7 and 9 years respectively.

Realized genetic gains were calculated for growth characteristics at the age of 9 years, by comparing the performance of the improved (selected) materials to unimproved materials (CC). For the first stage of selection (selection made in natural stands) gain of $6.0 \%$ for HT, $8.0 \%$ for diameter breast height (DBH) and $24 \%$ for volume were estimated. When $20 \%$ of the clones, with the lower breeding values are removed from the seed orchard (genetic thinning), an additional gain of $2 \%$ for $\mathrm{HT}, 3 \%$ for $\mathrm{DBH}$ and $8 \%$ for volume over the unrogued seed orchard is resulted. Thus, the total genetic gain from the genetically tested, first generation seed orchard of black pine at Koumani is estimated as $8 \%$ for HT, $11 \%$ for DBH and $32 \%$ for volume. These results indicate that improvement of black pine by selection, establishment of seed orchard and progeny testing the clones, is a very promising profitable operation.

Key words: Pinus nigra, Variance, covariance, heritability, correlation, rogued seed orchard, genetic test, genetic base, realized gain.

\section{Introduction}

Black pine (Pinus nigra Arnold) is a southern european species extending from Spain in the west to central Turkey in the east. In Greece covers an area extending from the southern part of Peloponnesos peninsula up to

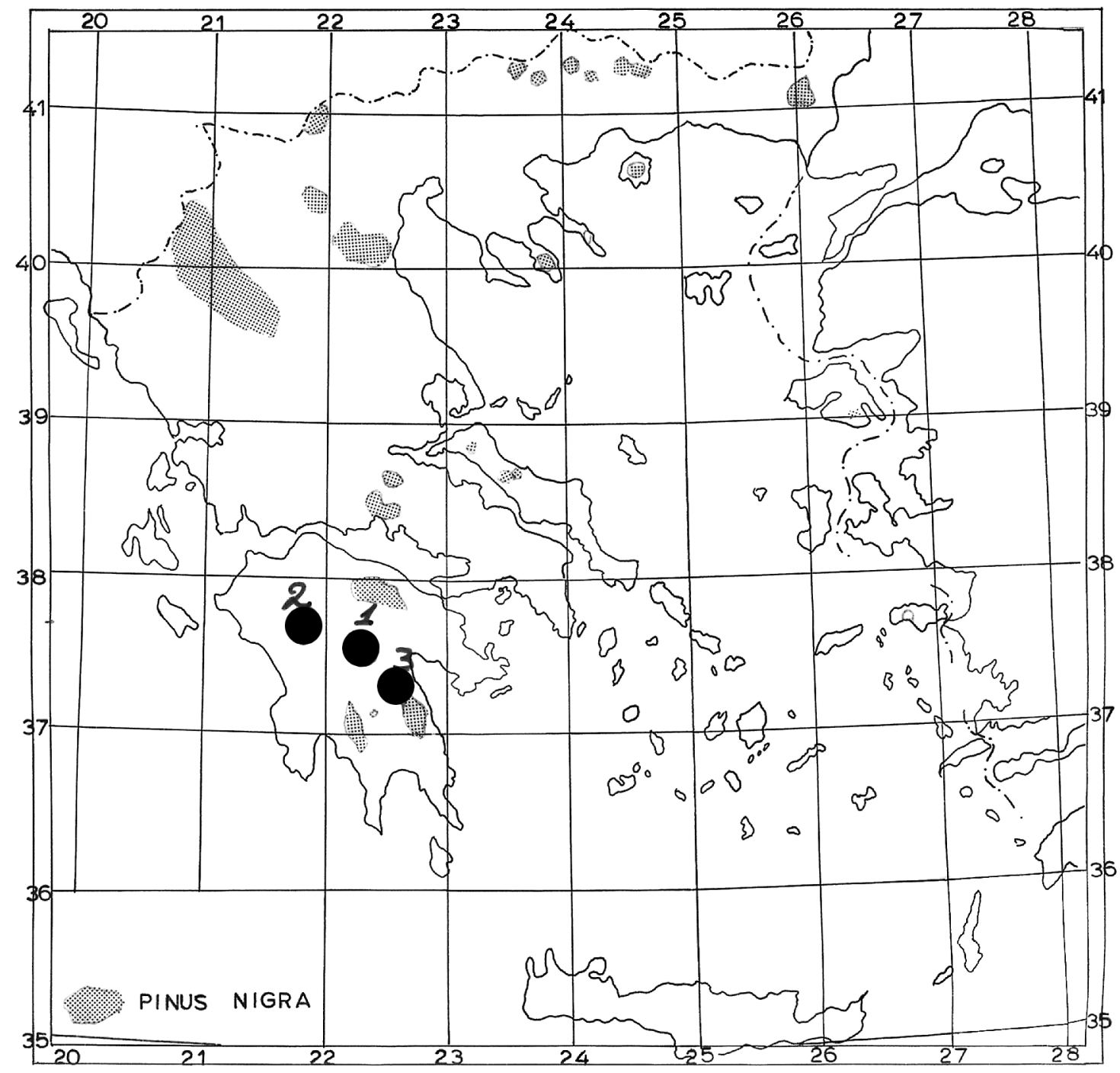

Figure 1. - Map of Greece showing the geographic distribution of Black pine and the locations of the experimental plantings ( 1 = Vlachokerasia, 2 = Raches, 3 = Vamvakou $)$. 
the northern border of the country (including the islands of Euboia, Thasos, Lesvos and Samos), forming many isolated populations. The natural distribution in Greece is shown in Figure 1. Silviculturaly it is considered one of the most important coniferous species that is extensively used in reforestation throughout the country.

The breeding program of the black pine in Greece is structured in three different populations (Southern, Central and Northern Greece). In 1978 the first clonal seed orchard has been established with a set of 52 intensively selected plus trees in the natural forests of black pine grown in the Peloponnesos peninsula. The reproductive maturity, i. e., the time at which the seed orchard starts producing adequate quantity of seed of desirable quality, has been attained at the age of 10 years (MATZIRIS, 1998). Since then appreciable quantities of seed are harvested yearly and used in reforestation. It is remarkable that at the age of 13 years (1991), a year of full cone production, the mean quantity of clean seed produced reached the amount of $200 \mathrm{~kg} / \mathrm{ha}$ with mean number of seeds per cone of 50 (MATZIRIS, 1998).

Since the selection of the plus trees was based on their phenotypic superiority, genetic evaluation, based on progeny testing, is mandatory for the roguing (genetic thinning) of the established seed orchard and upgrading the genetic quality of the seed produced. Collecting open pollinated (OP) seed by clone in years of full cone production, OP families are produced which are evaluated in field trials and estimates of the general combining ability are obtained.

The objective of this investigation is to study genetic variation in growth and quality characteristics in black pine, identify clones with low breeding value for roguing the seed orchard and estimate realized genetic gain from first generation clonal seed orchard.

\section{Material and Methods}

\section{Plant Material}

Open pollinated seeds were collected from all 52 clones included in a 10 ha seed orchard in 1989, a year of full cone production. All seed from a clone, regardless of the ramets from which they were collected, were considered to be members of the same open pollinated family; i. e., they all shared the same genetic mother. Seed were sown in the nursery (1990) in paper pots filled with sterilized mixture of peat moss and perlite (2:1). A year later 1991 three experimental plantings, located in Raches, Vlachokerasia, and Vamvakou, were established. In choosing test locations the rule that progeny tests were located on sites representative of the lands that are to be reforested was applied. All locations are within the broad area of Peloponnesos, southern part of Greece, within which the breeding materials of the seed orchard progenies are used.

At each location 52 families plus a control, also called commercial check (CC), were planted in randomized complete block design including 4 (Raches and Vamvakou) or 8 (Vlachokerasia) replications. Families plus CC were randomly assigned within replications in 10-tree row plot arrangement for Raches and Vamvakou and 4 tree rectangular plots for Vlachokerasia.

Since the geomorphology of the experimental planting of Vlachokerasia was quite heterogeneous, and in order to reduce the variability within replications, the number of replications was increased with equivalent reduction in plot size. The spacing in all plantings was $2 \times 3$ meters. The characteristics of the locations and the experimental plantings are shown in Table 1.

\section{Measurements}

Total tree height (HT) was measured, in all three locations, at the ages of 4,7 and 9 years. Breast height diameter (DBH) was only measured at the age of 9 years in Raches and Vlachokerasia; it was excluded in Vambakou since in this planting there were some short (below $1.4 \mathrm{~m}$ ) and therefore no measurable trees. At Raches the number of branches of uppermost whorl were counted and bole straightness and crown form were evaluated, according to a 5 point scale (1 very good, 5 very poor). For Vlachokerasia, total tree height (HT) and $(\mathrm{DBH})$ were used to estimate roughly the outside

Table 1. - Characteristics of the locations of the experimental plantings.

\begin{tabular}{|c|c|c|c|}
\hline Characteristic & Vlachokerasia & Raches & Vamvakou \\
\hline Latitude $\left({ }^{0} \mathrm{~N}\right)$ & 3720 & 3743 & 3716 \\
\hline Longitude $\left({ }^{0} \mathrm{E}\right)$ & 2224 & 2151 & 2234 \\
\hline Elevation ( $\mathrm{m})$ & 750 & 650 & 1100 \\
\hline Year of establishment & 1991 & 1991 & 1991 \\
\hline Number of families & $52+\mathrm{CC}^{1}$ & $52+\mathrm{CC}$ & $52+\mathrm{CC}$ \\
\hline Exper. Design & RCB & $\mathrm{RCB}$ & $\mathrm{RCB}$ \\
\hline Replications & 8 & 4 & 4 \\
\hline Plot size & 4 trees, rectangular & 10 trees, row & 10 trees, row \\
\hline Spacing $(\mathrm{m})$ & $2 \times 3$ & $2 \times 3$ & $2 \times 3$ \\
\hline Natural vegetation & $\begin{array}{l}\text { opening in Pinus, } \\
\text { nigra } \text { stands }\end{array}$ & $\begin{array}{l}\text { Arbudus, Erica } \\
\text { Quercus spp }\end{array}$ & $\begin{array}{l}\text { Opening in Pinus } \\
\text { nigra } \text { nat. stands }\end{array}$ \\
\hline Soil parent materials & Mica schist & $\begin{array}{l}\text { Tertiary siliceous } \\
\text { Deposits }\end{array}$ & Mica schist \\
\hline Rainfall/year (mm) & 1020 & 1100 & 950 \\
\hline Survivals at 9 years $(\%)$ & 96 & 85 & 76 \\
\hline Mean height at 9 years $(\mathrm{m})$ & 3.75 & 2.63 & 2.27 \\
\hline
\end{tabular}

${ }^{1} \mathrm{CC}=$ Commercial check or control. 
bark volume (VOL) for each tree, applying the conic volume equation:

$$
\mathrm{VOL}=0.25\left(3.14 \times \mathrm{DBH}^{2} \times \mathrm{HT}\right) / 3
$$

\section{Statistical Evaluation}

Data were checked for suspected outliers (measurements outside the normal values) before analyses. Such values may arise from various reasons, as recording errors during measurements or mechanical damages of trees in the growing sites.

Analyses of variance for each characteristic measured or assessed were conducted in two stages due to missing trees within plots and the need for the estimation of the within plot variance, following well established procedures (STONOCYPHER, 1966; SNEDECOR and CoCHRAN, 1968; NAMKOONG, 1979; BECKER, 1983). Initially the mean squares within plot variance $\left(\sigma^{2}{ }_{\mathrm{w}}\right)$ were estimated from individual tree data. Then analyses based on plot means were made applying the general model of twoway classification:

$$
\mathrm{Y}_{\mathrm{ij} .}=\mu+\mathrm{r}_{\mathrm{i}}+\mathrm{f}_{\mathrm{j}}+\mathrm{rf}_{\mathrm{ij}}+\mathrm{w}_{\mathrm{ij}}
$$

Where: $\mathrm{Y}_{\mathrm{ij} .}=$ The mean plot value of the $\mathrm{j}^{\text {th }}$ family that is in the $\mathrm{i}^{\text {th }}$ replication. All $\mathrm{Y}_{\mathrm{ij}}$. values are treated as if they had the same number of observations

$$
\begin{array}{ll}
\mu & =\text { overall mean } \\
\mathrm{r}_{\mathrm{i}} & =\text { effect of } \mathrm{i}^{\text {th }} \text { replication } \\
\mathrm{f}_{\mathrm{j}} & =\text { effect of } \mathrm{j}^{\text {th }} \text { family } \\
\mathrm{rf}_{(\mathrm{ij})} & =\text { interaction effect of families } \mathrm{x} \text { replications } \\
\mathrm{w}_{\mathrm{ij} .} & =\text { the mean of the } \mathrm{n}_{\mathrm{ij}} \text { deviations }
\end{array}
$$

The variance of plot means $\left(\mathrm{Y}_{\mathrm{ij}}\right)$ is $\sigma_{\mathrm{w}}^{2} / \mathrm{rf}\left(1 / \mathrm{n}_{11}+1 / \mathrm{n}_{12}\right.$ $\left.+\ldots . .1 / \mathrm{n}_{\mathrm{rf}}\right)=\sigma_{\mathrm{w}}^{2} / \mathrm{n}_{\mathrm{h}}$, where $\mathrm{n}_{\mathrm{h}}$ is the harmonic mean of the number of trees within plots. The within plot mean square variance $\left(\sigma_{\mathrm{w}}^{2}\right)$ was used for estimating heritability values, while the average variance of plot mean $\left(\sigma^{2} / n_{h}\right)$ is used in the analyses of variance for testing the reps $\mathrm{x}$ families interaction effect.

\section{Combined Analyses of Variance over Locations}

Genotype $\mathrm{x}$ environment interaction arises from the fact that some genes may have effects that differ from one environment to another. Such interactions, if exist, may cause decreased performance when a population selected under one environment is used under another. The size and extent of the interaction is very important for the movement of bread material of the forest tree species. Therefore, data of height growth measured at the ages 4,7 and 9 years, common to all (three) experiments, were pooled over locations and combined analyses of variance were performed following the procedures outlined in details by CochrAN and Cox (1968) and NAMKOONG (1979). Since the numbers of replications were not equal in all locations (four in Raches and Vamvakou and 8 in Vlachokerasia) and additionally the number of trees within plots was also varied, the analyses for getting the locations, families and families $\mathrm{x}$ locations effects were based on plot means.

Genotype $\mathrm{x}$ environment interaction $(\mathrm{G} \times \mathrm{E}$ ) effect at the family level was also tested for significance using the type B $\left(\mathrm{r}_{\mathrm{b}}\right)$ genetic correlation (YAMADA, 1962; PIRCHNER, 1969; BuRdon, 1977; LAMBETH, 1980; HodGe and WHITE, 1992; SIERRA-LuCERo et al., 2002). This correlation express the genetic relationship that may exist between measurements of the same characteristic taken in different environments and it is expressed as: $r_{b}=$ $\sigma_{\mathrm{f}}^{2} /\left(\sigma_{\mathrm{f}}^{2}+\sigma_{\mathrm{fp}}^{2}\right)$; Values of $r_{\mathrm{b}}$ near one indicates no $(\mathrm{G} \times \mathrm{E})$ interaction, while values near zero indicates highly significant interaction. The variance components of families $\left(\sigma_{\mathrm{f}}^{2}\right)$ and family $\mathrm{x}$ location interaction $\left(\sigma_{\mathrm{fp}}^{2}\right)$ were estimated from the pooled over location ANOVA.

\section{Genetic Parameter Estimates}

Mean squares were equated to expected mean squares and variance components and heritability estimates were obtained. It is known (NAMKOONG, 1979) that the degree to which family members are closely related is proportional to the degree to which families differ. Thus the variances among families $\left(\sigma_{\mathrm{f}}^{2}\right)$ obtained from the analyses are interpreted as one quarter of additive genetic variance.

$$
\sigma_{\mathrm{f}}{ }^{2}=\operatorname{Cov}(\text { H.S. })=1 / 4 \sigma_{\mathrm{A}}{ }^{2}
$$

Narrow sence heritability estimates on individual tree basis $\left(h^{2}\right)$ for each one characteristic and location were estimated as the ratio of the additive genetic variance $\left(\sigma_{\mathrm{A}}^{2}\right)$ to total phenotypic variance $\left(\sigma_{\mathrm{ph}}{ }^{2}\right)$ :

$$
\mathrm{h}^{2}=\sigma_{\mathrm{A}}^{2} / \sigma_{\mathrm{ph}}^{2}=4 \sigma_{\mathrm{f}}^{2} /\left(\sigma_{\mathrm{w}}^{2}+\sigma_{\mathrm{rf}}^{2}+\sigma_{\mathrm{f}}^{2}\right)
$$

The values obtained from the above formula are applicable in the specific environmental conditions under which they have been estimated and are biased upwards when are applied to different environmental conditions

\section{Estimation of Realized Gain}

In clonal seed orchards the trees originally selected in the first phase are crossed and the families produced are evaluated in field tests and estimates of the combining ability of the parental clones are made. The clones, which prove to be poor parents are rogued from the seed orchard and only the best (genetically tested) are left for future seed production. Realized genetic gains were estimated for both stages of the selection program i. e., for the unrogued and rogued clonal seed orchard of Koumany. The gains were calculated as previously described in another paper by MATZIRIS (2000). Since unimproved commercial checks (CC) were included in all plantings, the gain for the first stage of selection was computed by subtracting the mean of the unimproved (CC) from the overall mean of the families of the selected trees included in the seed orchard; the difference was expressed in percentage of the commercial check. After roguing the seed orchard on the basis of progeny testing (genetic thinning) an additional gain is resulted. This gain was calculated by subtracting the overall progeny mean of the test (excluding CC) from the mean of the reselected families, to be maintained in the seed orchard. Finally the total realized genetic gain from rogued clonal seed orchard was taken by the addition of the gain of the two stages of selection (mass selection plus progeny testing) 
Table 2. - Overall mean values for total tree height at the age of 4 (HT4), 7 (HT7) and 9, (HT9) years, diameter at breast height (DBH9) and tree volume (Vol.) at 9 years, of three open pollinated experimental plantings of Black pine grown in Greece.

\begin{tabular}{|llcc|}
\hline Characteristic & Vlachokerasia $^{1}$ & Raches & Vamvakou \\
\hline HT4 $(\mathrm{m})$ & $1.10(0.98-1.33)$ & $0.69(0.69-0.79)$ & $0.52(0.49-0.64)$ \\
& & $1.77(1.55-1.97)$ & $1.44(1.29-1.80)$ \\
\hline HT7 $(\mathrm{m})$ & $2.52(2.28-2.66)$ & $2.71(2.14-2.94$ & $2.41(1.91-2.90)$ \\
\hline HT9 $(\mathrm{m})$ & $3.86(3.28-4.39)$ & & \\
& & & \\
\hline DBH9 $(\mathrm{cm})$ & $6.9(5.5-8.2)$ & $0.113(0.050-0.192)$ & not estimated \\
\hline Vol. $\left(\mathrm{m}^{3} \mathrm{x} 100\right)$ & $0.532(0.313-0.804)$ & $85(55-100)$ & $70(50-90)$ \\
\hline Survival $(\%)$ & $96(81-100)$ & & \\
\hline
\end{tabular}

${ }^{1}$ Values in parenthesis are family mean ranges.

Table 3. - Estimates of component of variances and narrow sense heritability $\left(\mathrm{h}^{2}\right)$ on individual tree basis, of three open pollinated experimental plantings of Black pine grown in Greece.

\begin{tabular}{|lrrrrr|}
\hline Characteristic & \multicolumn{1}{c}{$\boldsymbol{\sigma}_{\mathbf{f}}^{\mathbf{2}}$} & $\boldsymbol{\sigma}_{\mathbf{r f}}^{\mathbf{2}}$ & \multicolumn{1}{c|}{$\boldsymbol{\sigma}_{\mathbf{w}}^{\mathbf{2}}$} & \multicolumn{1}{c|}{$\boldsymbol{\sigma}_{\mathbf{p h}}^{\mathbf{2}}$} & $\mathbf{h}^{\mathbf{2}}$ \\
\hline 1.VLACHOKERASIA & & & & & \\
HT4 & $61.426^{* *}$ & $36.361^{*}$ & 582.015 & 679.802 & 0.21 \\
HT7 & $219.341^{* *}$ & 506.374 & 1451.381 & 2177.096 & 0.40 \\
HT9 & $389.766^{* *}$ & 858.549 & 2334.049 & 3582.409 & 0.43 \\
DBH9 & $17.898^{* *}$ & 82.883 & 194.547 & 295.328 & 0.24 \\
Volume & $0.072^{* *}$ & 0.0652 & 0.0635 & 0.1359 & 0.21 \\
\hline 2.RACHES & & & & & \\
HT4 & $16.543^{* *}$ & 28.535 & 178.917 & 223.995 & 0.29 \\
HT7 & $90.975^{* *}$ & 269.000 & 122.579 & 1282.540 & 0.28 \\
HT9 & $225.458^{* *}$ & 489.654 & 2334.532 & 3049.646 & 0.29 \\
Branches/whorl & $0.023^{* *}$ & 0.069 & 0.082 & 0.174 & 0.53 \\
Straightness & $0.030^{* *}$ & 0.118 & 0.511 & 0.652 & 0.19 \\
\hline 3.VAMVAKOU & & & & & \\
HT4 & $12.829^{* *}$ & 16.052 & 135.257 & 164.138 & 0.31 \\
HT7 & $108.531^{* *}$ & 174.458 & 1234.749 & 1519.738 & 0.29 \\
HT9 & $280.271^{* *}$ & 598.816 & 2765.392 & 3845.063 & 0.31 \\
\hline
\end{tabular}

${ }^{1} \sigma_{\mathrm{f}}^{2}, \sigma_{\mathrm{rf}}^{2}, \sigma_{\mathrm{w}}^{2}, \sigma_{\mathrm{ph}}^{2}$, are variance components estimates for families, reps $\mathrm{x}$ families, within plot and total phenotypic variance, respectively.

\section{Results}

In Table 2 the mean tree heights per location at the age of 4,7 and 9 years as well as the $\mathrm{DBH}$, volume and survival at the age of 9 years are listed. Table 3 presents estimates of variance components and narrow sense heritabilities on individual tree basis $\left(\mathrm{h}^{2}\right)$. The variance component estimates for growth characteristics obtained from the pooled over locaction analyses are shown in Table 4. Finally, in Table 5 the estimated realized gains, at the age of 9 years, from the two stages of selection are presented.

\section{Discussion}

\section{Survival and Growth Characteristics}

Survival at the age of 9 years were variable among families and locations. At Vlachokerasia the survivals among the families were ranged from $81.2 \%$ up to $100 \%$ with overall mean of the test planting $95.9 \%$. Twenty families had $100 \%$ survival at the age of 9 years. This high survival is related to favorable growth conditions and specifically to very good high moisture holding capacity of the soil. In Raches with less favorable conditions the survivals varied among families from $55 \%$ up 
Table 4. - Estimates of variance components and narrow sense $\left(\mathrm{h}^{2}\right)$ heritability, for total tree height at the ages 4 (HT4), 7 (HT7) and 9 (HT9) years, from the combined analyses of variance over the three locations.

\begin{tabular}{|ccccc|}
\hline Characteristic & $\boldsymbol{\sigma}_{\text {f }}^{2}$ & $\boldsymbol{\sigma}_{\text {fl }}^{2}$ & $\boldsymbol{\sigma}^{2}{ }_{\mathbf{w} / \mathbf{r h}}$ & $\mathbf{h}^{\mathbf{2}}$ \\
\hline HT4 & 11.973 & 0.0 & 34.111 & 0.25 \\
HT7 & 63.646 & 0.0 & 216.874 & 0.23 \\
HT9 & 115.609 & 0.0 & 486.496 & 0.19 \\
\hline
\end{tabular}

${ }^{1} \sigma_{\mathrm{f}}^{2}, \sigma_{\mathrm{fl}}^{2}, \sigma_{\mathrm{w} / \mathrm{h}}^{2}$ are estimates of variance components for families, families x location interaction and within plot, respectively.

to $100 \%$ with overall mean $85 \%$. Finally in Vamvakou, survival was worst ranking among families from $50 \%$ up to $90 \%$ with overall mean $75.6 \%$. Analyses of variance (not presented) have shown that the diffenences among families within locations were statistically significant, while the differences among locations were highly significant. Total tree height at the age of 9 years was related to survival rate. It was higher $(3.86 \mathrm{~m})$ at Vlachokerasia with the highest survival and lowest $(2.41 \mathrm{~m})$ at Vamvakou experimental planting. The diffences among families, for total tree height at the ages 4,7 , and 9 years and volume at the age of 9 years, were statistically significant. Large variability among open pollinated families of black pine for growth traits, at the age of 10 years, has been also reported by ARBEZ and MiLLER (1972).

\section{Variance Components and Heritability Estimates}

Knowledge of variation and the degree of inheritance of the characteristics of interest are the fundamental basis upon which a well designed tree improvement program must be based. The estimates of variance components and the narrow sense heritability $\left(\mathrm{h}^{2}\right)$ for all characteristics studied have been presented in Table 3. Heritability estimates were variable depending on the location, age and characteristic to which they refere.

In Vlachokerasia the $\mathrm{h}^{2}$ for HT growth were $0.21,0.40$ and 0.43 at the ages of 4,7 , and 9 years, respectively. The $\mathrm{h}^{2}$ for $\mathrm{DBH}$ at the age of 9 year was found 0.24 and that for volume 0.21 . It seems that in this experimental planting the $\mathrm{h}^{2}$ values increase as trees become older. This was expected since the enviromental variation is reduced, as trees become older. Similar results have been also reported in slash pine (HoDGE and WHITE, 1992). They found that HT heritability increased from 0.05 at the age of 5 years to 0.1 at the age of 10 years.

In the planting of Raches the $\mathrm{h}^{2}$ values for HT were $0.29,0.28$ and 0.29 at the ages 4,7 and 9 years respectively, while the coresponding $\mathrm{h}^{2}$ values for 9 years $\mathrm{DBH}$ was 0.35 , and that for the number of branches per whorl 0.53. Heritability estimates of HT at the Vamvakou experimental planting were very close to those obtained from Raches (Table 3). Heritability values $\left(\mathrm{h}^{2}\right)$ for growth characteristics in black pine have been also studied by ARBEZ and MiLler (1972) at the age of 10 years; from the analysis of an open pollinated progeny test including 26 families they estimated $\mathrm{h}^{2}$ values of $0.35,0.20$, and 0.24 for total tree HT, DBH and volume respectively. These values are in close agreement with those found in the present study. The higher $\mathrm{h}^{2}$ values for HT at the ages of $7(0.40)$ and 9 (0.43) years, estimated in the Vlachokerasia planting, may be the result of the higher site quality of this location in comparison with the other two or the better site uniformity within replications. Early natural selection against the slower growing trees is expected to be stronger on better sites with the consequence the reduction of the environmental variance. SIERRA-LUCERO et al. (2002) working with loblolly pine found positive correlation $(r=0.54)$ between $\mathrm{h}^{2}$ and height growth, as well as, between $\mathrm{h}^{2}$ and mean annual increment $(r=0.67)$, indicating that site productivity influences positively $\mathrm{h}^{2}$ values. However there are contradictory results found in the literature. HODGE and WHITE (1992) found no relationship between $h^{2}$ values and site index in loblolly pine and concluded that the degree of genetic control and site uniformity were the same on sites of both high and low productivity. Narrow sense heritability for HT estimated from the pooled analyses of variance across the three locations were $0.25,0.23$ and 0.19 at the ages 4,7 and 9 years respectively (Table 4). The differences among families and among locations were highly significant, while the family $\mathrm{x}$ location interaction effect was insignificant in all ages. This indicates, that although there are some differences in the rankings of the families, the faster growing (on the average) remain in the top and the slower are found in the bottom. The type B genetic correlation $\left(r_{b}\right)$ at the family level was found close to unity, indicating that family ranks are relatively stable across locations. This is in agreement with insignificant family $x$ location interaction effect found from the pooled analyses of variance. The results obtained indicate that genotype $\mathrm{x}$ environment interaction is not a significant source of variation and therefore the seed produced from the clonal seed orchard of Koumani can be freely used over the environmental conditions of the three locations, that are representative of the broad area of Peloponnesos. Although, that there are strong interactions for a few families the genetic gain does not seem to be influenced when the best families are selected on the basis of average performance at all locations. Although the results obtained are based on relative young progeny tests ( 9 years), they can be used for preliminary decisions, such as initial roguing of the seed orchard. Limiting selection by culling the poorest families at the age of 9 years has been also recommended for ponderosa (Pinus ponderosa Lows.) and western white pine ( $P$. 
monticola Dougl.) (STEINHOFF, 1974). Other researchers such as, SiERRA-LuCERo, et al. (2002) for loblolly pine and SAMUEL et al. (2000) for Sitka spruce, found that there is no loss in selection efficiency by selecting at the age of 10 years. MCKEAND (1988), in order to increase the efficiency of the breeding and testing program at North Carolina State University-Cooperative Tree Improvement Program (NCSU-TIP) analyzed 18 firstgeneration progeny tests of loblolly pine to find the optimum time for growth assessment. Under reasonable assumptions for age-age correlation and heritability changes over time, he concluded that the expected genetic gain per year in the breeding program was the greatest for selection between 6 and 8 years. Since gain rates will be heavily influenced by time, early selection for seed production and for breed development will be advantageous (NAMKOONG, 1979; LAMBETH, 1980). However, these results must be interpreted with caution since age-age correlation is not always precisely estimated and the performance of the genotypes at young ages, in most of the cases, is imperfectly related to that at maturity (NAMKOOMG et al., 1980; LAMBETH, 1980; OLSON et al., 2001). It is of interest to keep in mind that juvenile selection is a form of indirect selection the efficiency of which is determined by heritabilities at the juvenile and mature age and the correlation that exists between the characteristics measured at these two ages

\section{Realized Genetic Gain}

Realized genetic gain was estimated at the age of 9 years. Data for HT, DBH and volume common to two locations (Raches and Vlachokerasia) were pooled and family means were obtained over the two locations. The Vamvakou location was not considered, since the DBH at this planting was not measured (there were many trees which at the age of 9 years were below $1.4 \mathrm{~m}$ ). The overall family mean values were $3.18 \mathrm{~m}, 5.4 \mathrm{~cm}$ and $0.2425 \mathrm{~m}^{3} \times 100$ for HT, DBH and volume respectively. The mean values for the commercial check (control) were $3.0 \mathrm{~m}$ for HT, $5.0 \mathrm{~cm}$ for DBH and $0.1962 \mathrm{~m}^{3} \mathrm{x} 100$ for volume. Therefore the realized gain for the selection made in natural stands is estimated $6.0 \%$ for $\mathrm{HT}, 8.0 \%$ for $\mathrm{DBH}$ and $24 \%$ for volume over the control (Table 5). Roguing $20 \%$ of the total number of the clones with the lower breeding value from the seed orchard an additional gain of $2 \%$ for $\mathrm{HT}, 3 \%$ for $\mathrm{DBH}$ and $8 \%$ for volume over the unrogued seed orchard is realized.

Economic studies (DAVIS, 1967; BERGMAN, 1968; BouVAREL, 1966; SHEPHERD and SleE, 1969) have shown that 2 to 5 percent increase in yield alone over the commercial plantings is enough to justify the cost of a tree improvement program. Therefore the realized gain $(8 \%)$ for volume, in the present study, resulting from roguing, makes it clear that roguing is a beneficial part of a tree improvement program and must be practiced if optimal expectations from the first generation seed orchard is to be obtained. The total gain from the first generation genetically thinned (rogued) seed orchard is summed to $8 \%$ for HT, $11 \%$ for $\mathrm{DBH}$ and $32.0 \%$ for volume (Table $5)$. Since the intensity of the second stage of selection was quite low ( $80 \%$ of the clones were saved and only the rest $20 \%$ were removed), higher gains should be expected if this intensity increases. However there is a need to keep broad the genetic base in the rogued seed orchard, in order to provide adequate genetic diversity in the improved commercial plantations. This is especially needed in black pine, with very long rotations (over 60 years), that require well-adapted trees with adequate genetic variation, capable to respond successfully to environmental conditions. Reduction of the genetic base of the seed produced can be also resulted from differential fertility of the clones, absence of flowering synchronization and embryo and gametophytic selection (MATZIRIS, 1994). The accumulation of inbreeding is faster and higher if the fertility of both parents varies (KANG et al., 2001). Furthermore, if the juvenile mature correlation is weak the first generation seed

Table 5. - Realized genetic gain for height (HT), diameter (DBH) and volume (VOL) from two stages of selection (mass selection plus progeny testing) at the age of 9 years (Raches and Vlachokerasia progeny tests combined).

\begin{tabular}{|c|c|c|c|}
\hline Characterisric & HT & DBH & VOL. \\
\hline Overall mean of all families & 3.18 & 5.40 & 0.2425 \\
\hline Mean of commercial check (CC) & 3.00 & 5.00 & 0.1962 \\
\hline $\begin{array}{l}\text { Realized genetic gain from selection made in } \\
\text { natural stands }\left(\Delta \mathbf{G}_{1}, \%\right)\end{array}$ & 6.0 & 8.0 & 24.0 \\
\hline $\begin{array}{l}\text { Mean of the } 80 \% \text { of the selected families ( } 20 \% \text { are } \\
\text { rogued on the basis of progeny testing) }\end{array}$ & 3.24 & 5.57 & 0.2629 \\
\hline Mean of all families & 3.18 & 5.40 & 0.2425 \\
\hline $\begin{array}{l}\text { Genetic gain from roguing } 20 \% \text { of the inferior } \\
\text { Clones after progeny testing }\left(\Delta \mathrm{G}_{2}, \%\right)\end{array}$ & 2.0 & 3.0 & 8.0 \\
\hline $\begin{array}{l}\text { Total genetic gain from genetically tested } \\
\text { (rogued) seed orchard, }\left(\Delta \mathbf{G}_{1}+\Delta \mathbf{G}_{2}\right)\end{array}$ & 8.0 & 11.0 & 32.0 \\
\hline
\end{tabular}


orchard cannot be rogued heavily when still young (LINDGREN, 1994). Realized genetic gain can be also increase by applying appropriate strategic use of the improved materials (Foster and KNOWE, 1995; Anonymous, 2001). On this base, some large Companies in the southeastern U.S.A. are collecting seed and keep it separately by mother tree, in order for seed of the higher genetic value to be used first. Seedlings of these genotypes may be used separately in single family blocks (mosaics) or they can be mixed prior to planting. Both operations have advantages and disadvantages which must be carefully considered (see, Foster and KNOWE, 1995).

Although the results of the present study are not directly comparable with other found in the literature, because of different species, age of evaluation, characteristics of interest and environmental conditions, some important results found in the literature are discussed here. Estimates of realized genetic gain in coniferous species have been reported in the past by many investigators (STONOCYPHER, 1969; ZoBEL et al., 1969, 1974; WEIR, 1973). MATZIRIS (1974) has reported results from an extensive study including 11 control pollinated progeny tests of loblolly pine (Pinus taeda L.) of the NCSUCIP grown in the southeastern USA. At age 10 years, realized genetic gain for volume production from first generation seed orchards was $18.0 \%$ in the north seed orchards and $16.0 \%$ in the south. By comparing predicted with actual realized gain he concluded that "Predicted genetic gain based on selection indices developed from reasonably accurate estimates of components of variance and covariance are good indicators of the actual realized gains". MATHESON et al. (1986) has shown that Pinus radiata trees from first generation seed orchards had considerable better growth (15-30\%) than the control seed lots. LI et al. (1999) reported that loblolly pine in the southeastern United States grown from seed of first generation seed orchard produced 7-12\% more volume per unit of area at harvest time, than trees grown from unimproved wild stands. SAMUEL et al. (2000) evaluating the tree improvement program of the U. K. reported that the realized genetic gains from first generation seed orchards were; $15-18 \%$ for Sitka spruce, $8-12 \%$ for Scots pine and $10 \%$ for Corsican pine. Departure from the ideal conditions in the seed orchard accumulate relatedness and inbreeding in the progeny and consequently affect the genetic quality of the seed produced (KANG et al., 2001).

The realized genetic gain in the present study has been estimated from relative young materials (9 years). Since the performance of genotypes at young ages in many cases are imperfectly related to that at maturity, further evaluation will be made as the trees become older.

\section{References}

Anonymous (2001): North Carolina State UniversityIndustry Cooperative Tree Improvement Program. Annual Report No.45. Department of Forestry, College Of Natural Resources, North Carolina State University, Raleigh, N. C., 24 pp.
BECKER, W. (1985): Manual of Quantitative Genetics. Academic Enterprise, Pullman, Washington, 190 pp.

BERGMan, A. (1968): Variation in flowering and its effect on seed cost-study of seed orchards of loblolly pine. Tech. Rept. N0. 38, School of Forest Resources, north Carolina State University at Raleigh, North Carolina.

BouvarEL, P. (1966): Economic factors in the choice of a method of forest tree breeding. Sexton Congreso Forestal Mudial, Madrit, Junio 1966, 6 CFM/G/C.T.I./6, PP 1-18.

BuRDon, R. D. (1977): Genetic correlation as a concept for studying genotype-environment interaction in forest tree breeding. Silvae Genet. 26: 168-175.

DAVIS, L. S. (1967): Investment in loblolly pine clonal seed orchards. Production costs and economic potential. J. For. 65: 882-887.

Dhakal, L, T. White and G. Hodge (1966): Realized genetic gain from slash pine tree improvement. Silvae Genet. 45(4): 190-197.

FALCONER, D. (1970): Introduction to Quantitative Genetics. The Ronald Press Company, N. York, 365 pp.

Foster, G. S. and S. A. Knowe (1995): Deployment and genetic gain. Proceedings of CRCTHF-IUFRO Conference, Hobart Australia. Eucalypt plantations: Improving fibre yield and quality, 469-478, p.

Hodge, G. R. and T. l. White (1992): Genetic parameter estimates for growth traits at different ages in slash pine and some implications for breeding. Silvae Genet. 41: 252-262.

KANG, K. S. (2001): Genetic gain and gene diversity of seed orchard crops. Swedish University of Agricultural Sciences, Silvestralia No. 187.

KANG, K. S. and D. LINDGREN (1999): Fertility variation among clones of Korean pines (Pinus Koraiensis S. et. Z.) and its implications on seed orchard management. For. Gen. 6: 191-200.

KANG, K. S., A. Bila, D. Lindgren and W. Choi (2001): Predicted drop in gene diversity over generations in the population where the fertility varies among individuals. Silvae Genet. 50(5-6): 200-205.

LAMBETH, C. (1980): Juvenile-mature correlations in Pinaceae and implications for early selection. For. Sci. 26(4): 571-580.

Li, B., S. McKeAnd and R. WeIR (1999): Tree improvement and sustainable forestry-impact of two cycles of loblolly pine breeding in the USA. For. Genet. 6: 229-234.

LINGREN, D. (1994): Intensity roguing in young seed orchards. In: LEE, S. J. (editor). Progeny testing and breeding strategies. Proceeding of the Nordic Group for Tree Breeding. Edimbugh, 1993, PP 14-22.

McKeAND, S. C. (1988): Optimum age for family selection for growth in genetic test of loblolly pine. For. Sci. 34: $400-411$.

Matheson, A. C., K. G. Eldridge, A. G. Brown and D. J. SPENCER (1986): Wood volume gains from first generation Radiata pine seed orchards. CSIRO Div. For Res. User Ser. No. 4, 13 pp.

MATZIRIS, D. (1974): Predicted versus Realized Gain in loblolly pine (Pinus taeda L.) improvement. Ph. D. Thesis, North Carolina State University, School of Forest Resources, Raleigh N. C. USA, 191 pp.

MATZIRIS, D. (1994): Genetic variation in the phenology of flowering in black pine. Silvae Gen. 43(5-6): 321-328.

MATZIRIS, D. (1998): Precocity of flowering and commercial maturity in a clonal seed orchard of black pine grown in 
Greece. Proceedings of International Conference, Bulgarian Academy of Sciences, Forest Research Institute Sofia, Vol. II 44-49 pp.

MATZIRIS, D. (2000): Genetic variation and realized genetic gain from Aleppo pine tree improvement. Silvae Gen. 49(1): 5-10.

NAMKOONG, G. (1979): Introduction to Quantitative Genetics in Forestry. U. S. Dep. Agri. Tech. Bull. No. 1588, $342 \mathrm{pp}$.

Namkoong, G., D. R. Barnes and J. Burley (1980): Screening for yield in forest tree breeding. Comonw. For. Rev. 59(1): 62-68.

OLsON T., D. LindGREN and B. LI (2001): Balancing genetic gain and relatedness in seed orchards. Silvae Gen. 50(5-6): 222-227.

Pepper, W. and G. NAmkoong (1978): Comparing efficiency of balanced mating designs for progeny testing. Silvae Genet. 27(3-4): 161-169).

Pirchner, F. (1969): Population Genetics in Animal Breeding. W. F. Freeman and Company, San Francisco, California, 270 pp.

SAmuel, C. J., A. John and S. J. LeE (2000): Fifty years of tree breeding in Great Britain. Forest Research, Northern Research Station, Roslin, Midlothian, U.K., 70 pp.

ShePheRD, K. R. and M. U. SleE (1969): Tree breeding programs and silvicultural practice in Australian manmade forests. Second World Cons. On FTB., FO-FTB69-9/9, 13 pp.
Sierra-Lucero, V., S. McKeand, D. Huber, D. Rockwood and T. WhiTE (2002): Performance differences and genetic parameters for four Coastal Provenances of loblolly pine in southeastern United States. Forest Sci., 48(4): 732-742.

SNEDECOR, G. and W. Cochran (1968): Statistical Methods. Iawa State Un. Press. AMCS, Iawa USA, 593 pp.

StonocypheR, R. W. (1966): The loblolly pine heritability study. Tech. Bull. No. 5, International Paper Company, Bainbridge, Georgia USA. 128 pp.

SteinhofF, R. (1974): Juvenile mature correlations in ponderosa and western white pine. Proceedings, IUFRO Joint Meeting of Working Parties on Population and Ecological Genetics, Breeding Theory and Progeny Testing, Stockholm. 243-250 pp.

WEIR, R. J. (1973): Realizing genetic gains through second generation seed orchards. Proc. Twelfth Southern Forest Tree Improvement Conf., Baton Rouge, Louisiana, 1973, 14-23 pp.

ZoBEL, B. J. (1974): Increasing productivity of forest lands through better trees. S. J. Hall Lectureship, University of California, Berkeley, California, 43 pp.

Zobel, B. J., R. Kellison and M. Mathias (1969): Genetic improvement of forest trees growth rate and wood characteristics in young loblolly pine. Proc. Tenth Southern Conf. On Forest Tree Improvement, Houston, Texas pp. $59-75$.

Zobel, B. J. and J. TAlBerT (1984): Applied Tree Improvement. John Wiley and Sons, N. York, USA, 505 pp.

\title{
Fertility Variation and Genetic Diversity in a Clonal Seed Orchard of Cryptomeria japonica
}

\author{
By K. S. KANG ${ }^{1), *}$, Y. A. El-KASSABY ${ }^{2)}$, M. S. ChUNG ${ }^{3)}$, C. S. KIM ${ }^{1)}$, Y. J. KANG ${ }^{4)}$ and B. S. KANG ${ }^{4)}$
}

(Received $16^{\text {th }}$ February 2005)

\begin{abstract}
Clonal differences in fertility (expressed as the number of female and male strobili) were determined for three consecutive years (2002-2004) in a clonal seed orchard of sugi (Cryptomeria japonica D. Don) in Korea. Fertility varied among clones and among years producing three-year averages of 196 and 652 for female and male strobili per ramet, respectively. Correlation

1) Tree Breeding Division, Korea Forest Research Institute, 44-3 Omokcheon-dong, Suwon, Kyonggi 441-350, Republic of Korea.

2) Department of Forest Sciences, Faculty of Forestry, University of British Columbia, Vancouver, British Columbia, V6T 1Z4, Canada.

3) College of Agriculture and Life Sciences, Kyungpook National University, 1370 Sankyuk-dong, Daegu 702-701, Republic of Korea.

$\left.{ }^{4}\right)$ Warm-Temperature Forest Research Center, Korea Forest Research Institute, 1253 Sanghyo-dong, Soguipo, Jeju 697-050, Republic of Korea.

*) To whom correspondence should be addressed:

(kangks@foa.go.kr, tel: +82 290 1120, fax: +82 292 4458).
\end{abstract}

between female and male strobilus production was positive over the three years and statistically significant in 2003, a good flowering year. Based on the observed fertility variation, the status numbers $\left(N_{s}\right.$, measure of genetic diversity) were calculated and varied from 25.6 to 31.7 among the three studied years. On average (pooled), relative status number was $86 \%$ of the census number $(N)$. Variation in female fertility was higher than that in male fertility, and this variation was reflected on female and male parents' status numbers. Pooled $N_{s}$ estimated from the three years was higher than that for any single year, implying that genetic diversity would increase when seeds collected from different years are pooled.

Key words: fertility variation, sibling coefficient, status number, effective number, flowering, sugi.

\section{Introduction}

Sugi (Cryptomeria japonica D. Don) was introduced to Korea in 1924 and has been widely planted on highly 